\title{
A sala de aula foi o meu mundo: a carreira do magistério em São Paulo (1920-1950)
}

\author{
Wiara Rosa Rios Alcântara \\ Universidade de São Paulo
}

\section{Resumo}

Nas primeiras décadas do século XX, dá-se a implantação, a expansão e a estruturação do sistema público de ensino paulista republicano. A criação de uma rede de escolas impulsiona a organização da carreira docente pela necessidade de formação de professores capazes de tornar tal expansão mais eficiente. Nesse período, foi estabelecido um conjunto de leis que normatizavam o exercício da profissão, fazendo dos professores funcionários do Estado. Ao lado da organização do sistema educativo, portanto, foi-se organizando também a profissão docente. Objetiva-se, aqui, problematizar a carreira e o trabalho docente em São Paulo a partir da experiência e da trajetória da professora paulista Botyra Camorim, tomando seu itinerário como representativo, pois a identidade de uma classe, de uma profissão, não pode ser considerada evidente independentemente das trajetórias dos membros que a compõem. Nesse movimento, acompanhar os fios de tal itinerário particular, inserido em meadas de relações, permitiu perceber a multiplicidade das experiências docentes, a pluralidade dos contextos de referência e as tensões que configuram limites e possibilidades ao fazer cotidiano. 0 confronto de fontes primárias - autobiografias, romances e contos escritos por Botyra Camorim - com a legislação, textos de educadores e pesquisas evidenciou que não se deve perseguir apenas a uniformidade e a homogeneização dos professores, pois os significados atribuídos ao trabalho docente e os modos de vivenciá-lo ou executá-lo não são perenes, mas estão intimamente relacionados com as condições espaço-temporais de exercício da profissão.

\section{Palavras-chave}

Carreira docente - Trajetória - Magistério primário - Experiência docente. 


\title{
The classroom was my world: the teaching career in São Paulo (1920-1950)
}

Wiara Rosa Rios Alcântara

University of São Paulo

\begin{abstract}
In the first decades of the twentieth century, the Republican public school system of the State of São Paulo was established, expanded and structured. The creation of a network of schools drove the organization of the teaching career motivated by the need to train teachers capable of making this expansion more efficient. During this period, a set of laws that regulated the profession was established, turning teachers into state civil servants. Thus, besides the organization of the education system, the teaching profession was also increasingly organized in São Paulo. The objective here is to problematize the career and the teaching work in São Paulo, based on the experience and trajectory of Botyra Camorin, a teacher in the state of São Paulo, taking her itinerary as representative, since the identity of a class, of a profession, cannot be taken as evident independently of the trajectories of its members. Along these lines, following the threads of this particular itinerary immersed in a web of relations made it possible to observe the multiplicity of teachers' experiences, the plurality of the contexts of reference, and the tensions that establish limits and possibilities to the everyday practice. Confronting the primary sources - autobiographies, novels and short stories written by Botyra Camorin - with the legislation, texts by educators and other studies revealed that we must not pursue solely the uniformity and homogenization of the teachers, because the meanings attributed to the teaching work and the ways to experience it or carry it out are not perennial, but are closely related to the spatiotemporal conditions of the exercise of the profession.
\end{abstract}

\section{Keywords}

Teaching career - Trajectory - Elementary teaching - Teaching experience. 


\begin{abstract}
A realidade difere, em quase tudo, da escola com que sonhou o noviço. Por isso mesmo, por ser vária e complexa, é mais viva, mais vibrante, mais humana.
\end{abstract} (ALMEIDA JUNIOR)

0 presente artigo é resultado de uma pesquisa de mestrado que teve como objetivo estudar o trabalho docente em São Paulo, na primeira metade do século XX, partindo da trajetória da professora paulista Botyra Camorim. A escolha por essa professora deveu-se a pelo menos dois fatores: a) sua trajetória permite pensar as trajetórias ordinárias, já que ela atuou nos diversos tipos de escola que compunham o sistema público de ensino paulista no período aqui delimitado; b) Botyra produziu autobiografias, livros de memória e romances sobre a profissão docente que, de um lado, sinalizam o modo como ela significa o magistério primário e, de outro, permitem acompanhar um itinerário individual que evidencia a multiplicidade de experiências, a pluralidade dos contextos de referência e a relação da experiência individual da professora com a classe e o cotidiano, na perspectiva da micro-história proposta por Jacques Revel (1998).

Quanto às categorias, a noção de trajetória possui aqui a conotação de trilhas "heterogêneas aos sistemas onde se infiltram e onde esboçam as astúcias de interesses e de desejos diferentes" (DE CERTEAU, 2003, p. 97). 0 estudo da trajetória tem o potencial de apontar os possíveis modos de ver e viver a profissão.

A concepção de trabalho docente, de profissão professor é tratada na perspectiva de António Nóvoa (1992). Observam-se diversas dimensões do ser professora que participam na constituição de subjetividades, minando a dicotomia entre o eu pessoal e o eu profissional. Para análise da carreira e do trabalho docente, opera-se utilizando os relatos autobiográficos como recurso metodológico fundamental, pois eles

favorecem o redimensionamento das experiências de formação e das trajetórias profissionais e tendem a fazer com que se infiltrem na prática novas opções, novas buscas e novos modos de conceber o ensino. (CATANI; BUENO; SOUSA, 1998, p. 46)

Diana Vidal (2006a) oferece ferramentas para este estudo quando, no II Congresso Internacional sobre Pesquisa (Auto)biográfica, interroga-se acerca das experiências de docência elaboradas pelos sujeitos ao longo de sua trajetória profissional. A autora põe em questão três dimensões da cultura profissional docente na elaboração da experiência do magistério: as condições materiais de trabalho, a convivência com a comunidade escolar e a instituição formadora. Contemplam-se aqui as duas primeiras.

Quanto às fontes, o uso de autobiografias e romances "resulta de uma compreensão ampliada da noção de documento proposta pela História Cultural" (MIGNOT; BASTOS; CUNHA, 2000 , p. 21). A renovação de métodos nas práticas de pesquisa

teve como objetivo a aproximação dos fazeres ordinários da escola, dos sujeitos da educação e das ações cotidianas, daí o crescente interesse pelas trajetórias de vida e de profissão. (VIDAL et al., 2004, p. 141)

Nesta investigação, ocupa uma posição central a autobiografia Uma vida no magistério, de Botyra Camorim, mas a problematização da narração histórica é feita pelo confronto de várias fontes. 0 trabalho do historiador é pensar as condições sociais que propiciaram dada abordagem sobre o vivido e não outra, considerando o estatuto indiciário da autobiografia. É com os indícios que a autobiografia pode oferecer a respeito das práticas que o historiador busca enriquecer a análise do social (REVEL, 1998).

Fundindo "texto e contexto numa interpretação dialeticamente íntegra” (CANDID0, 2006, p. 13), a pesquisa articula diversas dimensões da carreira e do trabalho docente: 1) as formas e possibilidades de ingresso na carreira; 
2) os desafios do trabalho nas primeiras escolas; 3) a relação da professora com a comunidade escolar; 4) as especificidades da atuação docente, conforme os diferentes tipos de escola; 5) as possibilidades e a luta das professoras para a ascensão na carreira. Essa divisão serve ao argumento central da análise: o estudo empírico do trabalho docente, por meio da análise das trajetórias de vida, evidencia quanto o trabalho docente é complexo, dinâmico, humano e, por isso, escapa às amarras em que pretendemos, por vezes, enquadrá-lo.

\section{Após muitos rogos [...], consegui que me mandassem para escolas vagas no interior: o ingresso na} carreira

A trajetória pessoal e profissional da professora paulista Botyra Camorim é significativa para o estudo das condições materiais de trabalho e dos significados atribuídos por professores ao exercício do magistério na primeira metade do século XX.

Nascida em 1910 na cidade de São Paulo, Botyra Camorim, descendente de italianos, viveu a infância e a juventude no bairro do Brás, onde também se deu toda sua formação escolar. Em 1928, diplomou-se professora primária na Escola Normal do Brás e casou-se com o contador mineiro Carlos da Silveira Gatti, com quem teve cinco filhos. Ela assumiu cadeira em escolas isoladas, reunidas e grupo escolar até 1959, quando se aposenta e cria para si um projeto de escritora.

Egressa da Escola Normal do Brás em 1928, Botyra solicita nomeação para o Grupo Escolar Marechal Deodoro na capital paulista, onde sua mãe havia exercido o magistério até 1924. Nessa escola, a recém-formada professora tem sua primeira experiência profissional como substituta efetiva ${ }^{1}$. Botyra não permanece mui-

1 - Começar a carreira como substituta efetiva era um meio de acumular pontos e conseguir melhores nomeações (RIBEIR0, 1990). No entanto, Almeida Junior (1935-1936) observa que o tempo de substituta efetiva, o estágio, contava muito pouco para efeitos de classificação em concurso para professor efetivo. to tempo como substituta efetiva, pois solicita às autoridades escolares a nomeação para ser professora em alguma escola.

A luta para conseguir trabalho, os pedidos a inspetores e ao próprio Secretário de Educação. Após muitos rogos, pois não havia o concurso de ingresso ao magistério, consegui que me mandassem para escolas vagas no interior. [...] Vi-me a caminho da primeira escola com o cérebro cheio de idéias e a mala repleta de planos de aula e compêndios. (CAMORIM, 1962, p. 21)

Os rogos a que Botyra refere-se eram dirigidos às autoridades escolares, geralmente quando não se conseguia nomeação via políticos. As condições em que os professores conseguiam escolas para lecionar apresentam elementos importantes para a compreensão do funcionamento do sistema e da política educacional daquela época (DEMARTINI, 1984).

0 caso dos padrinhos é mencionado por Almeida Junior (1951) em seu discurso de paraninfo para formandas da Escola Normal do Brás, no ano de 1923. Estimulando as normalistas a estudarem, ele adverte:

Encontrareis por ai discípulos do comodismo, que vos dirão: - Para que estudar? Se ao menos conseguíssemos melhorar de posição... Mas o govêrno lá se preocupa com o preparo e a competência dos professores? 0 que vale são os padrinhos! E, com grande gesto de revolta, disfarçam a razão verdadeira do descaso pelo estudo, isto é, a sua profunda e crônica preguiça. (p. 122)

Com isso, percebe-se que as nomeações a pedido não eram exceção, mas sim o caminho para o ingresso de muitas normalistas no magistério primário. 0 concurso era outro meio para se conseguir a escola, como relata Botyra:

Digo essas coisas por experiência própria e pelo que presenciei durante minha longa 
carreira, quando Delegados de ensino, às vezes até inspetores é que indicavam vagas escolares pelo sertão e povoados, sítios e fazendas distantes. E isso aconteceu comigo antes de ingressar como efetiva no magistério através do $1^{\circ}$ Concurso de Ingresso realizado no ano de 1933. (CAMORIM, 1986, p. 161, grifo nosso)

A tensão nesse momento do ingresso devia-se, em grande parte, à certeza de que a probabilidade de conseguir escolas bem localizadas era pequena. Esse temor aumentava pela falta de informação a respeito das condições e dos locais de instalação das escolas disponíveis. Alguns dados eram fornecidos pela Secretaria de Educação e, quase sempre, não correspondiam às reais condições de instalação da escola. "Como não era possível conhecer a escola antes de tomar posse, as surpresas eram muitas" (RIBEIR0, 1990, p. 104).

0 concurso ao qual Botyra se reporta possivelmente foi o instituído pelo Código de Educação por meio do Decreto $\mathrm{n}^{0} 5.884$, de 21 de abril de 1933. E quem poderia nele se inscrever? De acordo com o Anuário do Ensino (SÃo PAULO, 1935-1936), normalistas diplomadas por escolas normais do Estado e professores de formação equivalente, com idade entre $18 \mathrm{e}$ 45 anos. A classificação dos candidatos levava em consideração a média geral de psicologia, pedagogia e didática (prática de ensino e administração escolar); o tempo de exercício, em caráter efetivo ou em substituição em escolas oficiais; a duração do curso da escola onde se diplomou o candidato.

0 ingresso via concurso aparece também no romance Cristina, publicado por Botyra Camorim em 1968. A transcrição a seguir é um diálogo que a professora protagonista travou com sua irmã Miria quando se inscreveu para o concurso de ingresso ao magistério primário.

- Será por pouco tempo. Não desanime, por favor, Miria. Estou decidida. Para o ano entrarei em concurso e aos poucos irei chegando à Capital. [...]

- Você vai logo, Cristina? [...]

Abrindo o jornal, percorreu a longa lista de nomeações. [...] Lá estava seu nome. Havia conseguido finalmente o que tanto havia desejado. Tornar-se independente, conseguir uma escola para trabalhar, auxiliar a mãe e a irmã. Sentia alegria mas ao mesmo tempo seu coração entristeceu. Deixaria o lar. Enfrentaria o desconhecido. [...]

- Urupema é ótimo lugar. [...] A cidade era ao lado da estrada de ferro. (CAMORIM, 1968, p. 15-18)

A partir da classificação, as professoras recém-formadas poderiam escolher cadeiras vagas. Essa escolha frequentemente significava afastamento do lar e mudança de cidade.

Mas o que a normalista recém-formada poderia esperar do trabalho que iria exercer? 0 inquérito realizado por Almeida Junior, em 1927, com formandas da escola normal, é elucidativo quanto aos motivos de ingresso no curso normal e quanto à compreensão da carreira do magistério por parte das normalistas recém-formadas.

Almeida Junior (1951) destaca as seguintes respostas das alunas à referida questão. Uma aluna que está em dúvida diz: "Depois de descansar e engordar numa fazenda, é que vou resolver" (p. 114). Dentre as que não pretendem lecionar, há variadas alegações - uma pretende ser concertista ou professora de piano; outras "sentem fascinação muito brasileira pelo emprego público" (p. 115); outra se sente acanhada diante das crianças "e por isso fugirá ao magistério, indo procurar serviço nos laboratórios de química, onde não tenha que preocupar-se senão com as reações" (p. 115); duas admitem detestar a carreira e afırmam terem estudado "por tradição de família, segui-lo-ei se me faltar coisa melhor [...] só exercerei o magistério, se me faltar pão" (p. 115); outra declara que a "escola vai ser o lar que daqui a duas semanas 
vou fundar, casando-me, os alunos, os filhos aos quais vou aplicar tudo quanto aprendi, de pedagogia e de higiene" (p. 115).

Quanto às que vão ensinar a contragosto e por pouco tempo, as explicações são: "Lecionarei na fazenda de papai, até fazer o tempo; depois casar-me-ei” (p. 116). Outra afirma que será professora justiceira e amiga dos alunos, mas, "se arranjar emprêgo melhor, deixarei o ensino, que é profissão ingrata, porque se o aluno aprende, é porque é inteligente; se não aprende, o professor não presta” (p. 116).

Dentre as que só aceitavam cadeira na capital, ele destaca uma que vai ainda mais longe: "Quero uma boa colocação na Capital. Que o magistério me seja suave e sem decepções, como as de algumas professoras que conheço, e num meio sempre bom, entre colegas delicadas e sinceras" (p. 116). Para Almeida Junior, "esta deveria desde logo requerer uma cadeira no Paraíso" (p. 117). Por fim, depois das que só se contentarão com classe em grupo escolar, ele destaca as doze abnegadas. São "doze normalistas, uma dúzia de soldados abnegados, prontas à obediência, dispostas a levar a boa palavra aonde quer que seja” (p. 117).

A realização do inquérito tem a ver com a concepção de Almeida Junior acerca das formas de ingresso no magistério, sobretudo o magistério rural. Para ele, o sistema de concurso em vigor não permitia levar em conta se a professora tinha ou não tendência ruralista. Assim, a proposta do Diretor Geral do Ensino, em 1935, é que se averiguasse, desde a escola normal, a inclinação do professor por uma espécie de consulta individual e de ensaio das aptidões de cada um. Isso porque muitas professoras abandonavam as escolas assim que chegavam às comunidades rurais ou enfrentavam enormes dificuldades de adaptação ao estilo de vida na roça.

Desse modo, o período entre a formatura e o início da carreira constituía-se de incertezas e dúvidas que iam desde as motivações para ser professora primária, até os modos de ingresso no quadro do magistério público primário, passando pelas preocupações quanto às características das escolas e comunidades de trabalho. Eleny Mitrulis (1993) explica o peso desse momento afirmando que o exercício do magistério na escola isolada era o umbral que separava a proteção vivida nos últimos anos da adolescência junto à família e à escola normal e a iniciação profissional solitária e permeada de desafıos. É a respeito dessa iniciação na escola isolada rural que tratarei a seguir.

\section{O batismo de fogo na escola rural: o trabalho nas primeiras escolas}

Tratar das condições de trabalho nas escolas isoladas rurais permite circunscrever o início da carreira do magistério, visto que frequentemente as primeiras experiências profissionais davam-se nesse tipo de escola.

Conforme o Código de Educação de 1933, para efeito de primeira nomeação e promoção de professores havia, no período, quatro tipos diferentes de escolas primárias no Estado de São Paulo: as de $1^{\circ}$ estágio, localizadas em pontos de difícil acesso e que, por isso, exigiam a residência do professor no próprio local da escola; as de $2^{\circ}$ estágio, localizadas em pontos de fácil acesso, mas que exigiam a residência do professor no próprio local da escola; as de $3^{\circ}$ estágio, situadas em cidades populosas, o que permitia ao professor residir em outro lugar, viajando diariamente para dar aulas; e, por último, as de $4^{\circ}$ estágio, localizadas na capital e em seus arredores, permitindo que o professor residisse na capital.

Em geral, a primeira escola era de $1^{\circ}$ estágio, mais conhecida como escola isolada rural. As formandas esperavam, então, pelo batismo de fogo na escola rural. Mas o que era a tão temida escola isolada rural?

Almeida Junior (1951), tratando das grandezas e misérias do magistério rural, descreve de forma literária o processo de iniciação de uma professora na roça, revelando

2 - Título extraído da autobiografia da professora Felicidade Nucci (1985), intitulada Memórias de uma mestra-escola. 
o imaginário acerca das condições de vida e trabalho nesses locais:

Logo que se diplomou normalista, resolveu transportar para uma escola de bairro os seus dezoito anos e sua alegria de moça. Ia um pouco por espírito de aventura, como quem vai "brincar de professora”, e muito por necessidade, esperando poder ter, com o ordenado, mais fartura de vestuário e menos limitações ao seu desejo de divertir-se. Foi nomeada. Tomou o trem, viajou quatro horas. Desceu numa estação solitária, perdida em pleno sertão, onde um trole sonolento a esperava. Andou mais três horas, subindo morro, descendo morro, sôbre caminhos empoeirados e ásperos. A viagem parecia nunca terminar, com o tédio daquele rodar monótono das rodas na areia. [...] Chegou à fazenda. No casarão velho e soturno, morava a família do administrador. Era ali que ela ia ficar, num quarto de telha vã, sem janela, pegado ao deposito de arreios. [...] À noite, recolheu-se ao quarto, que cheirava a graxa; trancou-se; deitou-se na cama de tábua, sôbre um colchão ruidoso, de palha de milho, apagou a vela. E então, lembrando-se daquele sertão em que estava, do rodar monótono do trole por subidas e descidas; pensando naquela gente com quem ia conviver, no modo porque falavam, no jeito com que comiam, na figura dos seus futuros alunos, - a imagem da Capital, de envolta com a lembrança da mamãe e das irmãs, lhe veio à memória como uma coisa distante, longínqua, perdida para sempre, - e pos-se a chorar devagarinho, como uma criança. (p. 130-131).

Narrativas semelhantes à descrita por Almeida Junior podem ser encontradas nas obras de Botyra Camorim, nas quais emergem memórias do trabalho docente em escolas isoladas:
Refiro-me à luta do mestre para vencer os obstáculos que encontra quando é enviado para escolas distantes da cidade, em lugar sem recursos. Moradia, condução, falta de material escolar, falta de apoio e compreensão de pais de alunos, as exigências de fazendeiros, do inspetor do quarteirão uma autoridade nas pequenas povoações e tantas coisas que surgem de acordo com o meio que o mestre irá conhecer, convivendo com pessoas estranhas, em ambiente nos quais nem sempre se adaptam desde o clima, alimentação, viver diário. (CAMORIM, 1986, p. 160)

A possibilidade de as professoras primárias fugirem a essa situação era muito remota, pois a Lei $\mathrm{n}^{\circ} 2.269$, de 31 de dezembro de 1927, em seu artigo 25, postulava que o professor diplomado só poderia ser nomeado para reger escola urbana depois de 200 dias de efetivo exercício em escola rural.

Vale salientar que essa obrigação restringia-se às normalistas formadas nas escolas normais livres e nas escolas normais oficiais com duração de três anos, em maior número no Estado. Estariam dispensados do estágio em zona rural os egressos da Escola Normal da Praça e os formados no regime das escolas normais de cinco anos e no curso ginasial completo.

Esse não era o caso de Botyra e da maioria das normalistas paulistas. Temerosas com a distância e com as condições de trabalho nas escolas rurais, as novas professoras dirigiamse ao interior na expectativa de logo voltarem para mais perto de seus locais de origem.

0 próprio modo de criação e funcionamento da escola isolada gerava uma instabilidade no início da carreira, tal como relatado por Botyra em sua autobiografia intitulada Uma vida no magistério. Quando de seu primeiro deslocamento para a zona rural, ela chegou a lecionar em três escolas diferentes em curto espaço de tempo. A primeira foi fechada por falta de alunos. 
Em Poço Preto fiquei quasi cinco meses trabalhando num barraco feito em dois dias, usando um banco da capela. Não havia material escolar. Lapis e papel, o prefeito da vila mandara a meu pedido. Meus alunos em número de dezeseis, a muito custo conseguira quasi implorando aos pais para mandarem à escola. Criança era necessária na roça. Faltavam muito. Alguns eram doentios. Sofriam de amarelão. Dois meses depois de aberta a escola, a matricula registrava apenas nove alunos. E não havendo alunos, a escola não podia funcionar. Era fechada. Fui dispensada e a Delegacia enviou-me para outra escola cuja professôra estava licenciada. (CAMORIM, 1962, p. 25)

Na segunda, Escola de Santa Maria, a professora voltou da licença.

Fiquei na fazenda. Velho casarão de taipas, tão grande, tão cheio de quartos que eu tinha medo de tudo. [...] 0 fazendeiro era dono do lugar. Da água, das casas, da lenha, da escola, de tudo. [...] Esperei muito tempo, ansiosamente a visita do inspetor da região. No dia em que êle apareceu, foi para me dizer que a professôra havia desistido da licença. Eu estava dispensada. (p. 26 e 33)

E na última, onde encontrou uma escola digna do nome de escola, a professora efetiva deixou o convento e iria voltar. Por isso, completamente desiludida, Botyra resolve retornar para São Paulo.

$\mathrm{Na}$ impossibilidade de fugir da escola rural, o caminho mais fácil era procurar uma comunidade que ficasse nas proximidades das ferrovias, o que facilitava não somente o acesso à escola, mas também o retorno da professora ao seu lugar de origem. 0 aumento da urbanização e o movimento econômico em torno da cultura do café, ainda no final do século XIX, favoreceram o crescimento da população em torno das ferrovias. Tal crescimento gerou uma demanda por mais escolas nessas regiões.
Esse também é um tema central na autobiografia de Botyra, que exerceu parte de sua profissão em escolas criadas nas proximidades das ferrovias, as quais muitas vezes dão nome aos capítulos de sua autobiografia. Assim, Zona da Paulista, Sorocabana e Central do Brasil são as referências geográficas que sua memória constrói e por meio das quais ela localiza o leitor. As ferrovias significavam, para a professora, a possibilidade de sair daquele mundo distante e voltar ao mundo civilizado - "meu bairro em São Paulo" (p. 96).

Quanto à criação, as escolas isoladas, conforme Decreto $\mathrm{n}^{0} 3.858$, de 11 de junho de 1925, deveriam ser localizadas pelo Diretor Geral da Instrução Pública nos núcleos de analfabetos que melhores condições oferecessem para seu funcionamento, sendo nucleo de analphabetos uma área de $2 \mathrm{~km}$ de raio em que se verificasse a existência de vinte a trinta crianças matriculáveis com idade entre 7 e 12 anos, conforme o artigo 22. 0 mesmo decreto, em seu artigo 24, postulava que seriam

supprimidas as escolas [isoladas] e cursos nocturnos que, em tres visitas successivas do inspector districtal, não apresentarem frequencia média legal.

Quanto ao funcionamento, nos casos em que nem o governo nem a fazenda providenciavam o material para as escolas, os custos ficavam por conta do professor e dos próprios alunos (DEMARTINI, 1984).

Por isso, no Anuário de 1935-1936, Almeida Junior aponta os vários problemas da escola rural, denominando-os de sete pecados capitais. 0 primeiro era a dificuldade de acesso. Para ele, a difusão do ensino rural era limitada pela falta de um sistema de comunicação.

0 segundo pecado capital era a situação de dependência da professora, que era maior quanto menor e mais atrasado fosse o núcleo escolar.

A sala de aula é obtida por favor especialíssimo, e á custa da própria moça. Também 
o alojamento e a pensão. A condução tem que ser pleiteada. (ALMEIDA JUNIOR, 1935-1936, p. 196)

Ao chegar nessas propriedades "arranchase a moça na casa do caipira” (p. 196). É aí que Almeida Junior (1935-1936) localiza o terceiro pecado capital: o desconforto.

A dona da casa, embora excellente pessoa, cozinha mal; desconhece o asseio; pita e cospe o dia inteiro, para todos os lados. Destinam à professora um quarto esburacado, também deposito de arreios. (Estou reproduzindo um quadro real que se repete com variantes). Água difícil; ausência de installações sanitárias [...] Algumas quando voltam para casa, nas férias, a família mal as reconhece; perderam varios kilos de peso. (p. 196)

Diante de tais condições, o Diretor do Ensino defende que há bairros "immaturos para escola”, pois, antes de nomear professoras, seriam necessárias estradas, saneamento, casa de moradia e de aula. Daí decorre o quarto pecado capital: o isolamento, resultado da falta de comunicação e do contraste entre a cultura da professora e a do roceiro. "A professora sente-se só. Quando escrevem aos paes ou ás autoridades uma carta de desespero, haverá quem não as lamente?” (p. 197).

0 isolamento estava tanto na vida comunitária quanto no trabalho escolar. Desse modo, trabalhando só, faltava estímulo - o quinto pecado.

Com tudo isso, o professor não tinha oportunidade de continuar aprimorando-se. Aí estava o sexto pecado capital: a dificuldade de cultivar-se, que se somava à falta de recursos para o ensino - esta, o sétimo pecado capital da escola rural paulista.

Até o final da década de 1940, Botyra atua em escolas rurais e suas narrativas apontam as difíceis condições de trabalho da professora primária. Nesse aspecto, tais narrativas contêm elementos que ajudam a problematizar as representações da professora acerca das escolas rurais e das comunidades em que estavam localizadas.

\section{Num costuma na roça: a professora}

\section{e a comunidade rural}

Que representações do trabalho docente em escolas isoladas Botyra transmite para suas colegas mais jovens a quem endereça sua autobiografia Uma vida no magistério? Para a professora, as populações rurais tinham um estilo de vida precário que se expressava:

\section{- Na habitação:}

Nhá Lucinda, minha hospedeira, levou-me para mostrar o quarto. Era um cômodo junto à cozinha, separado por meia parede. A porta sem trinco ficava apenas mal encostada. Lamparina de azeite pendurada na parede por um arame grosso. 0 catre, com colchão de palha de milho e a um canto, pás, enxadas e foices. Um cipó estendido de uma parede a outra, fazia de cabide para as roupas. Uma janelinha estreita, mal deixava entrar a luz. (CAMORIM, 1962, p. 24)

Na segunda escola isolada em que trabalhou, ela ficou numa fazenda cuja casa descreve com a mesma ojeriza:

Velho casarão de taipas, tão grande, tão cheio de quartos que eu tinha medo. Pela noite, ouvia-se de tudo. Ruídos no telhado, portas e janelas que estalavam. Ratazanas passeavam no meu quarto. Havia um porão cheio de velharias, ninho para toda espécie de animal. (p. 26)

\section{- Na alimentação:}

Nosso alimento era pobre em tudo. Diariamente, era feijão com farinha, às vezes um pouco de arroz, ôvo frito. Pão não havia. Tomávamos café com farinha de milho. (p. 24) 
- Na linguagem:

Meu véio já tem roça pra oiá. Depois, isto num é nosso memo, praque prantá (p. 25)

- Nas festividades:

0 Forricôco. dançam em volta do boi, representado por um homem dentro de uma armação com o formato de animal. Pulam e cantam sob o compasso cadenciado dos bambus amedrontando os ouvintes. Tive a impressão de estar diante de uma tribu de índios. (p. 28)

Congada [...] pela primeira vez eu assistia aquelas festas (p. 30)

[...] só de assistir me entonteceu [...] É um barulho ensurdecedor [...] o resto daquela semana foi difícil trabalhar. (p. 32)

Outro problema identificado nas escolas rurais, não somente por Botyra, mas também pelos administradores do ensino, eram as crendices que impediam a população de procurar soluções científicas principalmente para as questões de saúde. Por isso, havia diversas recomendações para que a professora ensinasse às jovens mães como cuidar de seus filhos e interviesse nos hábitos de higiene dos alunos. 0s relatos de Botyra também são elucidativos em relação a esse ponto:

Por tôda roça, sempre notei que impera as crendices e abusões. Todos conhecem remédios para as doenças. São poucas as famílias que levam os filhos ao médico na cidade. Uns por falta de recursos, outros por falta de hábito. Na roça não falta quem benza contra bucho virado, espinhela caída, mau olhado. Atrás das portas há sempre uma ferradura e orações. Vi de tudo por esse interior e pouco ou nada uma professora pode fazer. Muitas vezes quando aconselhava alguma cousa, que era fora das idéias do povo, eu me arriscava a per- der amizades tão enraizadas estão as crenças e costumes. Às futuras mães, era difícil aconselhar. As moças já estavam preparadas. No pescoço, pendurados em cordão, já havia bentinhos, dentes de alho e figas. Sempre há curiosas que resolvem o caso muito bem, quando tudo é normal, pois em casos difíceis, é morte na certa. Quanta criança vi morrer com o mal de sete dias, tudo por falta de higiene e cuidados! Há muito que fazer por este São Paulo a fora! (CAMORIM, 1962, p. 84)

0 choque entre a cultura da professora e a do roceiro que a hospeda, conforme salientou Almeida Junior, acentuava a solidão da professora do ponto de vista pessoal e profissional. Nessas narrativas, a professora sempre mostra o espanto diante da cultura do sertão, como no relato a seguir, transcrito de Coisas que acontecem:

Aqueles dois quilômetros ou mais, que eu andava a pé da sede da fazenda até a escola, no verão pareciam mais longos. 0 almoço que me serviam sempre arroz, feijão e ovo frito, tudo salpicado com muita pimenta, provocaram uma sede insaciável.

Um dia, passando por uma das casas da colônia, vi uma senhora esfregando mesas e cadeiras no terreiro. Parei e pedi um pouco d'água, que logo foi servida em caneca de folha. Uma água fresca, quase gelada, tão diferente daquela que era usada na minha escola, tirada de uma bica distante, água turva, pesada e morna.

Quando agradeci ela me disse.

_ Por que usa sempre essa sombrinha? A senhora me descurpe mas, precisa tomar sol. Por isso, é assim amarela...

Não achando o que responder, perguntei a ela se a água servida era de poço ou vertente, água tão fria, quase gelada.

E ela: _ A água está assim fresca, porque ponhei duas rãs no pote. 0 gelo delas passa p'ra água... (CAMORIM, 1986, p. 132) 
Em sua forma, essa narrativa revela o estilo de Botyra, ou seja, o uso das experiências escolares na composição de contos e romances; em seu conteúdo, evidencia as tensões advindas do encontro, no espaço escolar, de diferentes culturas - a cultura da professora e a cultura da população pouco alfabetizada; a cultura da cidade e a cultura da roça.

$\mathrm{Na}$ perspectiva de Botyra, o estilo de vida, os hábitos, os costumes e as doenças das populações rurais impediam que seu trabalho fosse realizado conforme sonhava.

Eu continuava com o meu trabalho na escola. Havia pouco aproveitamento. 0 amarelão fazia as crianças desanimadas e faltosas. (p. 32)

De acordo com os relatos de Almeida Junior, a escola isolada, tal como estava organizada, apresenta-se como empecilho ao bom rendimento escolar. A escola que possuía as características da escola isolada foi o modelo mais criticado nesse período de expansão e organização do sistema escolar.

Com isso, não se pretende estabelecer um olhar negativo acerca da diversidade cultural na e da escola. Pelo contrário. Faz-se necessário, em texto posterior, refletir sobre esse encontro de diferentes culturas no espaço escolar, sobre os impactos da relação da professora com a comunidade no interior da sala de aula, e sobre os modos como tal diversidade configura culturas escolares.

Ao lançar mão dos relatos de Botyra, não se objetiva, no âmbito deste artigo, discutir ou problematizar as representações da professora acerca da comunidade escolar. Interessa evidenciar representações de uma professora, nascida e formada na zona urbana, acerca da população rural com a qual trabalhava, representações estas que possivelmente correspondiam aos discursos da escola normal, de educadores e higienistas sobre a ignorância, as crendices e os costumes populares. No entanto, o que aqui se busca destacar é que os professores classificam e atribuem significados à comunidade escolar e vice-versa. Essa relação entre o professor e o público com o qual trabalha também configura uma cultura docente: a maneira pela qual o trabalho dos professores é exercido e o modo como a escola é recebida e vista pela própria comunidade escolar.

\section{A escola reunida, o grupo escolar e o instituto de educação}

As escolas reunidas expressavam o modo pelo qual o sistema escolar foi-se adaptando às pressões da demanda educacional, pois a reunião de escolas (três classes agrupadas, cabendo a direção a um dos professores em exercício) foi uma medida adotada em bairros e vilas onde se verificava a aglomeração de crianças e havia impossibilidade de implantação do grupo escolar devido aos critérios legais estabelecidos para a criação dos mesmos.

Na administração de Sud Menucci como Diretor Geral do Ensino, os estabelecimentos de ensino primário do Estado que possuíam oito classes ou mais foram classificados como grupos escolares de primeira ordem; os que possuíam de quatro a sete classes tornaram-se grupos escolares de segunda ordem. As escolas reunidas, a partir de então, seriam os estabelecimentos de ensino com três classes, cabendo a direção, cumulativamente, a um dos professores em exercício. Essa escola era considerada de baixo custo, pois seus professores eram pagos como os de escolas isoladas. Devido ao baixo custo, escolas que obedeciam aos critérios para serem transformadas em grupo escolares permaneciam como escolas reunidas com um grande número de classes.

As escolas reunidas significavam certo avanço na carreira, pois estavam localizadas em locais menos isolados, com maior densidade populacional e, portanto, com mais infraestrutura que as escolas isoladas. Além disso, a despeito de a escola de cada professora funcionar independentemente da outra, a existência de colegas no mesmo local de trabalho permitia 
a realização de reuniões pedagógicas e a troca entre os pares. Porém, ainda assim, o objetivo de um número significativo de professoras era chegar a um grupo escolar, de preferência próximo a seu local de origem. É o caso de Botyra, que sempre tentava voltar para São Paulo a cada concurso de remoção para o qual se inscrevia:

com a lista na mão cheguei-me a um mapa de São Paulo que estava a meu lado e ali, escolhi um nome marcado pelo pontinho negro mais próximo de São Paulo, minha querida terra. (CAMORIM, 1962, p. 73.

Embora tenha sido removida do sertão, ela continuava persistindo no mesmo objetivo:

Em busca do meu ideal, trabalhar na minha terra, inscrevi-me novamente em concurso, conseguindo remoção para uma cidade mais próxima de meu São Paulo! (p. 79).

Na escola da Zona da Paulista, Delegacia de Campinas, Botyra obteve boa promoção. 0 número de alunos promovidos e a frequência média da classe sob responsabilidade do professor eram os critérios para classificação nos concursos de remoção (MITRULIS, 1993). Assim, no concurso seguinte, a professora conseguiu remoção para o primeiro grupo escolar em que trabalhou; ficava em Sabaúna, distrito de Mogi das Cruzes, onde Botyra passou a residir, fazendo viagens diárias.

Tal grupo provavelmente se enquadrava entre aqueles denominados de segunda ordem, porque foi extinto no ano em que Botyra se removeu devido ao fato de não haver a quantidade de alunos necessária para funcionar acima de três classes. Com isso, o diretor e todos os professores foram removidos para a capital, mas Botyra foi nomeada para uma das duas classes da $2^{\text {a }}$ Escola Mista de Sabaúna. A indignação da professora é menos com a extinção do grupo e mais com o fato de somente ela não ter sido nomeada para a capital: "Não achei explicação. A outra classe seria regida por professora substituta. Comecei a trabalhar em classe super lotada" (CAMORIM, 1962, p. 87).

Em Sabaúna, Botyra trabalhou nove anos, mas "com o correr do tempo, meus filhos cresciam e precisavam continuar os estudos" (p. 87). Por isso, ela solicitou remoção para um grupo em Suzano, "subúrbio de São Paulo [...] distante apenas vinte minutos da cidade [Mogi das Cruzes] com condução fácil” (p. 94) e onde seus filhos poderiam estudar.

[Em] mil novecentos e cinqüenta, fui removida por concurso para a cidade onde há anos fixara residência. Aquele sonho acalentado, o velho sonho de ser professora no meu bairro em São Paulo [...] deixava de existir. (p. 96)

Embora não tenha conseguido mudarse para São Paulo, Botyra encerrou a carreira num estabelecimento de ensino que era modelo para a região - o Instituto de Educação Dr. Washington Luís de Mogi das Cruzes.

Em 1946, o Decreto Federal $n^{0} 14.152$ incorpora a Escola Normal de Mogi das Cruzes ao Colégio Estadual de Mogi das Cruzes. É sob essa organização que Botyra é removida para a referida escola no início da década de 1950. Mas logo depois, em 1954, a Escola Normal é transformada em Instituto de Educação, nos termos do Decreto-Lei Federal $n^{0}$ 8.530, de 2 de janeiro de 1946.

0 Instituto de Educação tinha como pressuposto organizacional a reunião de um conjunto de cursos. No caso do Instituto de Mogi das Cruzes, os cursos eram:

I- Curso Normal, de três anos, destinado à formação de professores primários e pré-primários;

II- Curso Primário, de cinco anos, subdividido em primário comum de quatro anos e complementar de um ano;

III- Curso Pré-Primário (Jardim da Infância), de três anos.

Além desses, havia os seguintes: Curso de Administradores Escolares de grau primário, 
para habilitação de diretores, orientadores do ensino, inspetores escolares, auxiliares de estatística e encarregados de provas e medidas escolares; cursos de especialização em Educação Pré-Primária, Didática Especial de Curso Complementar Primário, Didática Especial de Ensino Supletivo, Desenho e Artes Aplicadas, Música e Canto.

Foi aí que Botyra não somente encontrou condições de trabalho para obter melhor rendimento escolar, como também ascendeu na carreira, tornando-se diretora do Curso Primário anexo à Escola Normal do Instituto de Educação.

\section{É maravilhoso orientar e dirigir tantas crianças: a ascensão na} carreira

No período em que Botyra atuou como professora, não apenas se deu a expansão do sistema educacional paulista, mas simultaneamente se assistiu a um aumento progressivo do número de mulheres, sobretudo no magistério primário. Essa presença, cada vez mais notável, tornou-se objeto de discussões que tinham a ver com as lutas de representação acerca de diversas concepções de feminilidade e masculinidade.

Tais concepções interferiam nos lugares que, dentro da carreira e do trabalho docente, eram atribuídos a homens e mulheres. No ponto de vista de Daiane Pincinato (2007), existem valores associados à masculinidade e à feminilidade construídos socialmente e, portanto, carregados de sentido histórico, dando significado às relações sociais. Essas relações não podem ser naturalizadas, mas devem ser sempre remetidas às suas referências históricas e sociais. Por isso, a autora questiona-se acerca do que é construído como feminino ou masculino na sociedade e na profissão docente.

Na nossa sociedade, o modelo masculino é formado por valores e significados que estão, na maioria das vezes, relacionados ao poder, à autoridade e ao prestígio social.
Nesse sentido, os cargos considerados masculinos também devem dispor de tais características, oferecendo àqueles que o executam a possibilidade de desfrutar desses privilégios e encarnarem esse modelo. Por outro lado, constatou-se, por meio do estudo da História do Magistério, que os valores femininos atribuídos à ocupação deve-se, em muito, à ideologia da vocação para o cuidado das crianças, devido à associação feita entre o exercício do magistério e a condição natural de ser mãe. (PINCINATO, 2007, p. 162)

Assim, na perspectiva de Pincinato (2007), o magistério foi sendo concebido como uma profissão feminina

não somente por causa da preponderância do número de mulheres, mas também pelos valores e significados sociais que a ela acabaram sendo associados como a idéia de vocação. (p. 45)

Tais significados, segundo a autora, estão ligados às relações de poder aí presentes.

Em função disso, Pincinato (2007) defende que a ascensão na carreira por parte dos homens não está motivada apenas pela busca de melhores salários, pois,

por trás da migração masculina para os cargos administrativos, encontram-se as mais diversas representações sobre o que significa ser homem na nossa sociedade e o desejo, mesmo que inconsciente, de afirmação da masculinidade, uma vez que homens que ingressam no magistério se vêem atuando em uma profissão considerada feminina. (p. 55)

\section{Entretanto,}

não bastava ser homem para prosseguir na hierarquia do magistério. Era necessário, além disso, fazer parte de determinadas 
redes de poder para se chegar aos cargos mais altos. (p. 166)

No caso de Botyra, sua ascensão ao cargo de diretora do Curso Primário anexo à Escola Normal do Instituto de Educação não se deu via concursos ou especializações. As relações que construiu na instituição e na cidade de Mogi das Cruzes favoreceram que, após licença da diretora, ela - e não outra professora fosse escolhida para assumir o cargo. Mas é somente no ano anterior à aposentadoria que tal acontecimento se dá. Daí a ressalva que a professora faz em sua autobiografia sobre um professor recém-formado que já era diretor, enquanto ela, formada há muito mais tempo, continuava como professora de escola isolada.

0 Diretor das Escolas Reunidas de Vila Poranga era um jovem professor, recémformado, dono de um dos três caminhões que existiam no lugar. Além de professor, ele explorava o negocio de carretos. Transportava o algodão dos bairros distantes para as cidades. Nas reuniões, ele não titubeava em criticar e até as professoras que eram quatro do seu grupo e cinco de escolas isoladas, inclusive eu. (CAMORIM, 1962, p. 44)

Nessa narrativa emerge outra problemática quanto à presença dos homens no magistério: a busca de outros trabalhos para complementar os vencimentos. Mas essa não era uma especificidade dos homens, ainda que fosse mais recorrente entre eles.

Não somente os homens tinham outros trabalhos para completar o salário de professor, mas também as mulheres, que poderiam ser professoras de piano, de datilografia etc., além da possibilidade de lecionarem em mais de uma escola ao mesmo tempo. No período em que lecionava em Sabaúna, simultaneamente, Botyra dava aula de datilografia e piano para aumentar a renda familiar, considerando que tinha cinco filhos para sustentar.
Há anos passados, por motivos que não vêm ao caso, eu mi vi responsável pela manutenção do lar cheio de crianças e não ganhava, como professora, o suficiente para mantê-las. Pois dei aulas de piano e datilografia na querida Sabaúna. Nesta cidade, em ocasião da crise com a morte do pai dos meus filhos, comecei um trabalho extra, o de datilógrafa copista, aceitando de alunos e professores os mais diversos trabalhos. (CAMORIM, 1986, p. 159)

Assim, se o salário era insuficiente, não o era somente para os homens, mas também para mulheres que se viam diante da necessidade de sustentar família numerosa. Além disso, nem sempre era possível conjugar as atividades da escola com as domésticas, devido também às condições de trabalho, à distância da escola e à necessidade de fazer longas viagens para se chegar a ela.

0 trabalho das professoras primárias, bem como a inserção da mulher no magistério não se deu sem lutas, tensões e disputas entre mulheres e homens. Delimitar, aqui, as condições de ingresso na carreira, de remoção e de exercício da profissão ajuda a compreender um pouco do funcionamento do sistema e da cultura escolar que favorece a ascensão dos homens aos postos administrativos.

Nesse sentido,

Ampliar os diálogos com a produção sobre gênero nos permitiria discutir, por exemplo, os significados da feminização do magistério para além do aumento do número de mulheres nos postos de docência, esmiuçando as condições de trabalho; as múltiplas relações que professoras estabelecem com a hierarquia (masculina? feminina?) [...]; as diversas maneiras como respondem a demandas criadas pela sociedade e lidam com as ansiedades e angústias da sua própria vida (ser mãe, esposa, celibatária, solteira, filha etc.). (VIDAL, 2006b, p. 24) 
Os elementos destacados por Vidal (2006b) e outros aqui desenvolvidos - as formas de ingresso, as primeiras experiências escolares, as condições de trabalho, a relação entre a professora e a comunidade escolar, as expectativas de ascensão, questões de gênero, conciliação de diferentes papéis revelam as tensões e complexidades em meio às quais se dá o exercício da profissão. Olhar tais elementos sob uma perspectiva histórica favorece uma percepção mais crítica da carreira e do trabalho docente, considerando os desafios e dilemas pessoais e profissionais na confıguração dos limites e das possibilidades do fazer dos professores e professoras, em dado contexto histórico-cultural.

\section{Considerações finais}

Este artigo propôs-se a problematizar a carreira e o trabalho docente, em São Paulo, a partir da experiência e da trajetória da professora paulista Botyra Camorim. A contribuição desta investigação reside na análise empírica, na persecução de um itinerário particular que, inserido em meadas de relações, elucida as possibilidades de construção da carreira do magistério na primeira metade do século XX.

As análises indicam que, a despeito do número significativo de pesquisas que se debruçam sobre a temática, investigá-la sob uma perspectiva histórica, considerando a experiência e as trajetórias individuais, é fundamental para evidenciar os modos heterogêneos, estratégicos e táticos pelos quais os professores respondem aos desafios do cotidiano escolar.

0 trabalho docente possui uma historicidade que não pode ser compreendida apartada das experiências (também historicamente construídas) e das trajetórias individuais. 0 modo como, hoje, os professores e as professoras percebem e exercem seu trabalho não está desconectado de uma experiência histórica da classe, mas também só pode ser compreendido na análise das condições e possibilidades do contexto de exercício da profissão.
Do ponto de vista metodológico, a produção literária de Botyra Camorim, sobretudo a autobiografia Uma vida no magistério, ocupa um lugar central. Ela propicia a compreensão de como os sujeitos representam, por meio da escrita, as tensões em relação à forma de iniciação na carreira; os desafios entre as características da escola e o trabalho em sala de aula; o impacto das representações da comunidade sobre a escola e vice-versa; a luta para ascensão na carreira. Os estudos autobiográficos permitem articular essas diversas dimensões, evidenciando que as

vidas minúsculas também participam, à sua maneira, da 'grande' história da qual elas dão uma versão diferente, distinta e complexa. (REVEL, 1998, p. 12)

Assim, a escolha pelo individual não é vista aqui como contraditória à escolha pelo social, pois o problema não é opor, e sim "reconhecer que uma realidade social não é a mesma dependendo do nível de análise” (p. 12), da escala de observação.

Por tudo isso, no estudo do trabalho docente, não se deve perseguir apenas a uniformidade e a homogeneização dos professores, afinal, os significados atribuídos ao trabalho docente e os modos de vivenciá-lo ou executá-lo não são perenes, mas estão intimamente relacionados com as condições espaço-temporais de exercício da profissão. No entanto, o entrelaçamento de trajetórias individuais pode permitir-nos perceber continuidades históricas, modos de ser docente e de viver a docência compartilhados por gerações, por saberes imemoriais que constituem a experiência coletiva do magistério. Na trama das recorrências e das rupturas, podemos, assim, recusar a atribuição de uma linearidade à história da profissão, reconhecendo que as maneiras de experienciar a docência produzem-se no mosaico do possível e do pensável, das tradições e dos desafios concretos enfrentados pelos professores em sua faina cotidiana. 


\section{Referências}

ALMEIDA JUNIOR, Antonio Ferreira de. A escola rural. In: SÃO PAULO (Estado). Secretaria Diretoria Geral da Instrução Pública. Anuário do Ensino do Estado de São Paulo. São Paulo, 1935-1936. p. 180-287.

. A escola pitoresca e outros trabalhos. 2. ed. São Paulo: Companhia Editora Nacional, 1951.

CANDIDO, Antonio. Literatura e sociedade. Rio de Janeiro: Ouro sobre azul, 2006.

CATANI, Denice; BUENO, Belmira; SOUSA, Cynthia. Os homens e o magistério: as vozes masculinas nas narrativas de formação. In:___ (Orgs.). A vida e o ofício dos professores: formação contínua, autobiografia e pesquisa em colaboração. São Paulo: Escrituras Editora, 1998. p. 45-64.

DE CERTEAU, Michel. A invenção do cotidiano 1: artes de fazer. 9. ed. Tradução de Ephraim Ferreiara Alves. Petrópolis, RJ: Vozes, 2003.

DEMARTINI, Zeila de Brito (Coord.). Velhos mestres das novas escolas: um estudo das memórias de professores da Primeira República em São Paulo. São Paulo: Centro de Estudos Rurais e Urbanos, 1984.

MIGNOT, Ana Chrystina V.; BASTOS, Maria Helena C.; CUNHA, Maria Teresa S. (Orgs.). Refúgios do eu: educação, história e escrita autobiográfica. Florianópolis: Mulheres, 2000.

MITRULIS, Eleny. Os últimos baluartes: uma contribuição ao estudo da escola primária: as práticas de inspeção escolar e de supervisão pedagógica. Tese (Doutorado) - Faculdade de Educação, Universidade de São Paulo, São Paulo, 1993.

NÓVOA, António. 0 passado e o presente dos professores. In: NÓVOA, António et al. Profissão professor. 2. ed. Porto: Porto Editora, 1992. p. 13-34. (Col. Ciências da Educação)

PINCINATO, Daiane A. V. Homens e masculinidades na carreira do magistério: uma escolha pelo possível, um lugar para brilhar (São Paulo, 1950-1980). Tese (Doutorado) - Faculdade de Educação, Universidade de São Paulo, São Paulo, 2007.

REVEL, Jacques. Jogos de escalas: a experiência da microanálise. Rio de. Janeiro: Editora Fundação Getúlio Vargas, 1998.

RIBEIRO, Ricardo. Inspeção e escola primária em São Paulo: trabalho e memória. Dissertação (Mestrado) - Faculdade de Educação, Universidade de São Paulo, São Paulo, 1990.

VIDAL, Diana. Experiências de docência e formação. In: SOUZA, Elizeu C. de; ABRAHÃO, Maria Helena (Orgs.). Tempos, narrativas e ficções: a invenção de si. Porto Alegre: EDIPURS, 2006ª p. 335-346.

Um olhar sobre os estudos de gênero em história da educação no Brasil. In: MORAIS, Christianni; PORTES, Écio; ARRUDA, Maria Aparecida (Orgs.). História da educação: ensino e pesquisa. Belo Horizonte: Autêntica, 2006b. p. 11-26.

VIDAL, Diana et al. A cultura escolar como categoria de análise e como campo de investigação a história da educação brasileira.

Educação e Pesquisa, São Paulo, v. 30, n. 1, p. 139-160, jan./abr. 2004. 


\section{Fontes}

CAMORIM, Botyra. Uma vida no magistério. São Paulo: Saraiva, 1962.

. Cristina. Mogi das Cruzes: [s.n.], 1968.

. Coisas que acontecem. São Paulo: Oficinas da Sociedade Impressora Pannartz Ltda, 1986.

NUCCl, Felicidade. Memórias de uma mestra-escola. São Paulo: [s.n.], 1985.

SÃo PAULO (Estado). Decreto no 3.858, de 11 de junho de 1925. Reforma a Instrução Pública do Estado. Coleção das Leis e Decretos do Estado de São Paulo. 2. ed. São Paulo: Imprensa Oficial do Estado, 1925. Tomo XXXV, p. 309-327.

Lei no 2.269, de 31 dezembro de 1927. Reforma a Instrução Pública do Estado. Coleção das Leis e Decretos do Estado de São Paulo. 2. ed. São Paulo: Imprensa Oficial do Estado, 1927. Tomo XXXVII, p. 274-281.

Secretária da Educação e da Saúde Pública. Decreto nº 5.884 de 21 de abril de 1933. Institui o Código de Educação do Estado de São Paulo. Coleção das Leis e Decretos do Estado de São Paulo. 3 ed. São Paulo: Imprensa Oficial do Estado, 1933. Tomo XLIII, p. 278-449.

. Secretaria Diretoria Geral da Instrução Pública. Anuário do Ensino do Estado de São Paulo. São Paulo, 1935-1936.

Recebido em: 24.02.2011

Aprovado em: 16.05.2011

Wiara Rosa Rios Alcântara é mestre e doutoranda em Educação pela Universidade de São Paulo, na área temática História da Educação e Historiografia. Atuou durante cinco anos como professora titular de ensino fundamental I na Rede Municipal de Ensino de São Paulo. Membro do Núcleo Interdisciplinar de Estudos e Pesquisas em História da Educação (NIEPHE-USP). Bolsista FAPESP. 